\title{
PELATIHAN SENAM JANTUNG SEHAT DAN PENILAIAN TINGKAT PENGETAHUAN MASYARAKAT TERKAIT HIPERTENSI DI DESA CIBEUREUM WETAN, KECAMATAN CIMALAKA, KABUPATEN SUMEDANG
}

\author{
Yunisa Pamela $^{1,2^{*}}$, Astrid Feinisa Khairani ${ }^{1,2}$, Nandina Oktavia ${ }^{1,2}$, Mohammad Iqbal ${ }^{2,3}$, Shintiya \\ Devi Siregar ${ }^{4}$, Raissa Fidela Andrini ${ }^{4}$, M. Takhsinul Qulub ${ }^{5}$, Ester Sari Silitonga ${ }^{5}$, Desi \\ Ramadhani ${ }^{6}$, Muhammad Hisyam Jaelani ${ }^{7}$, Dinda Lestari ${ }^{8}$ \\ ${ }^{1}$ Departemen Ilmu Kedokteran Dasar, Fakultas Kedokteran Universitas Padjadjaran \\ ${ }^{2}$ Pusat Studi Sistem Kesehatan dan Inovasi Pendidikan Tenaga Kesehatan, Fakultas Kedokteran, \\ Universitas Padjadjaran \\ ${ }^{3}$ Departemen Ilmu Penyakit Jantung dan Pembuluh Darah, Fakultas Kedokteran, Universitas Padjadjaran \\ ${ }^{4}$ Fakultas Pertanian, Universitas Padjadjaran \\ ${ }^{5}$ Fakultas Ilmu Sosial dan Ilmu Politik, Universitas Padjadjaran \\ ${ }^{6}$ Fakultas Ilmu Budaya, Universitas Padjadjaran \\ ${ }^{7}$ Fakultas Ekonomi dan Bisnis, Universitas Padjadjaran \\ ${ }^{8}$ Fakultas Kedokteran Gigi, Universitas Padjadjaran \\ E-mail: yunisa.pamela@unpad.ac.id
}

\begin{abstract}
ABSTRAK. Hipertensi merupakan salah satu penyebab utama kematian di dunia. Di Indonesia, hipertensi merupakan penyebab kematian nomor lima pada semua umur. Hipertensi bisa jadi merupakan penyakit keturunan, namun gaya hidup turut berperan sebagai faktor risiko terjadinya hipertensi. Modifikasi gaya hidup yang diketahui dapat mencegah hipertensi adalah aktivitas fisik yang dilakukan secara teratur, misalnya senam. Pelatihan senam jantung sehat telah dilakukan kepada masyarakat di Desa Cibeureum Wetan untuk membantu pencegahan hipertensi. Sebanyak 30 orang peserta berpartisipasi dalam pelatihan senam yang diakhiri dengan pemberian video senam jantung sehat kepada perwakilan warga. Selain senam, dilakukan juga penyebaran kuesioner untuk mengetahui tingkat pengetahuan masyarakat mengenai hipertensi. Sebanyak 26 peserta dengan rentang usia 23 hingga 65 tahun telah mengisi kuesioner dengan lengkap. Sebagian besar peserta menjawab 7 pertanyaan dengan benar dari 11 pertanyaan yang diberikan. Setelah dilakukan pelatihan senam jantung sehat, masyarakat diharapkan dapat mengadakan pelatihan senam secara mandiri dan teratur. Beberapa usaha seperti pendidikan kesehatan dapat dilakukan kepada warga untuk membantu meningkatkan tingkat pengetahuannya mengenai hipertensi, sehingga dapat meningkatkan kesadaran warga untuk secara mandiri mencegah hipertensi.
\end{abstract}

Kata kunci: hipertensi; modifikasi gaya hidup; senam jantung sehat

ABSTRACT. Hypertension is one of the most common disease leads to mortality worldwide. In Indonesia, hypertension is the fifth leading cause of death. Hypertension might be a hereditary disease, but lifestyle also contributes as one of its risk factors. A lifestyle modification activity that might help to prevent hypertension is regular physical activity, one of which being gymnastic. We trained healthy heart gymnastic to the community at Desa Cibeureum Wetan to help the prevention of hypertension. Thirty participants were involved in the gymnastic exercise ended by giving a gymnastic video for the community to self-exercise. We also analysed the knowledge level of hypertension of the community using questionnaire. Twenty-six participants aged 23 to 65 years old filled the questionnaire, most of which answered 7 correct questions out of 11. Have been trained gymnastic, we expected the community can held a gymnastic exercise independently and regularly. Several measurements like health education might be given to the community to increase their knowledge about hypertension, to help increasing the self awareness in preventing hypertension.

Keywords: gymnastic; hypertension; lifestyle modification

\section{PENDAHULUAN}

Hipertensi atau penyakit yang umum dikenal sebagai darah tinggi, merupakan salah satu penyebab utama kematian di seluruh dunia. Sebanyak 45\% kematian yang diakibatkan oleh penyakit jantung adalah karena adanya faktor risiko hipertensi. Lima puluh satu persen kematian dari penyakit stroke didahului oleh adanya penyakit hipertensi.(World Health Organization, 2013) Di Indonesia, hipertensi juga merupakan salah satu masalah besar, yaitu penyakit penyebab kematian nomor lima pada semua umur, sebagaimana disampaikan pada data Sample
Registration System Indonesia (SRS) tahun 2014. (Kementerian-Kesehatan, 2019)

Hipertensi bisa jadi merupakan penyakit keturunan, namun hipertensi juga erat kaitannya dengan sikap dan faktor terkait gaya hidup. Beberapa gaya hidup yang dapat menjadi risiko munculnya hipertensi yaitu konsumsi garam berlebih (dalam bentuk sodium), tidak cukup konsumsi kalium (dari buah dan sayur), memiliki berat badan berlebih, jarang berolah raga, serta terlalu banyak mengkonsumsi alkohol dan merokok. (WHO Regional Office for South-East Asia, 2011) Oleh karena itu, salah satu cara mencegah hipertensi 
adalah dengan memodifikasi gaya hidup.

Beberapa kegiatan terbukti dapat mencegah hipertensi misalnya mengkonsumsi makanan sehat yang banyak mengandung buah dan sayur, mengurangi asupan garam, mengurangi asupan makanan yang kaya akan lemak jenuh, menjaga berat badan ideal, dan rajin melakukan aktivitas fisik seperti berolah raga. Hipertensi juga dapat dikendalikan dengan cara tidak merokok, membatasi minum minuman beralkohol, teratur memeriksakan tekanan darah, segera berobat jika sudah terdiagnosis menderita hipertensi, serta mencegah dan mengobati penyakit lain seperti diabetes.(WHO Regional Office for South-East Asia, 2011)

Salah satu bentuk olah raga yang diketahui dapat memberikan pengaruh pada penyakit hipertensi adalah senam. Dari penelitian yang dilakukan pada lansia di Surakarta maupun Semarang, senam diketahui dapat menurunkan tekanan darah sistol maupun diastol. (Sirait, Saraswati, \& Udiyono, 2018; Totok \& Fahrun, 2017) Senam juga diduga dapat meningkatkan kualitas hidup pada penderita hipertensi.(Setiawan \& Wungouw, 2013) Salah satu kegiatan senam yang umum dilakukan masyarakat adalah senam jantung sehat. Senam jantung sehat adalah kegiatan senam aerobik yang lengkap terdiri dari pemanasan, latihan, dan pendinginan. Senam jantung sehat ditujukan untuk meningkatkan kinerja jantung. (Murbawani, Ss, \& Subagyo, 2012) Senam ini juga diketahui dapat memberikan efek baik terhadap kadar glukosa maupun lipid darah. (Fakhrudin \& Nisa, 2013; Murbawani et al., 2012)

Dalam rangka kegiatan pengabdian masyarakat di Desa Cibeureum Wetan, Kecamatan Cimalaka, mahasiswa dan dosen Universitas Padjadjaran (Unpad) yang tergabung dalam kelompok Kuliah Kerja Nyata $(\mathrm{KKN})$ terintegrasi hibah riset fundamental Unpad bertema model mencit hipertensi mengadakan pelatihan senam jantung sehat terhadap para kader setempat. Selain peragaan senam jantung sehat, disebarkan juga kuesioner yang bertujuan untuk mengetahui tingkat pengetahuan para kader terhadap hipertensi. Para kader diharapkan dapat menjadi garda terdepan dalam edukasi kesehatan kepada masyarakat awam, salah satunya pengetahuan mengenai hipertensi.

\section{METODE}

\section{Senam jantung sehat}

Program pengabdian pada masyarakat (PPM) yang terintegrasi $\mathrm{KKN}$ ini merupakan program berbasis komunitas yang bertujuan untuk meningkatkan kemampuan masyarakat agar dapat menyelesaikan masalahnya sendiri. Tim PPM mengundang para kader di Desa Cibeureum Wetan,
Kecamatan Cimalaka, Kabupaten Sumedang untuk dapat hadir pada kegiatan pelatihan senam jantung sehat dan pengisian kuesioner yang diadakan pada tanggal 9 Desember 2019 di aula desa.

Tim PPM sebelumnya berlatih senam secara mandiri dari video senam jantung sehat yang tersedia pada youtube. Peragaan senam dicontohkan menggunakan instruksi dengan Bahasa Indonesia sehingga diharapkan dapat dengan mudah dimengerti dan diikuti oleh peserta. Sebelum bersama-sama melakukan senam, terlebih dahulu dilakukan pengecekan tekanan darah pada peserta. Pada saat kegiatan, seluruh tim PPM memperagakan gerakan senam jantung sehat yang terdiri dari pemanasan, gerakan inti, serta pendinginan. Selain melakukan peragaan senam kepada kader dan warga, tim PPM juga memberikan video senam jantung sehat kepada perwakilan desa.

\section{Kuesioner tingkat pengetahuan hipertensi}

Selain kegiatan senam jantung sehat, dilakukan juga penyebaran kuesioner yang bertujuan untuk mengetahui tingkat pengetahuan peserta teradap hipertensi. Pengisian kuesioner dibantu oleh tim PPM. Kuesioner berisikan pertanyaan mengenai identitas dan 11 pertanyaan mengenai pengetahuan tentang hipertensi. Kuesioner sebelumnya telah divalidasi pada kegiatan survey KKN yang mendahului kegiatan PPM senam jantung sehat. Selain pertanyaan mengenai pengetahuan hipertensi, terdapat juga 9 pertanyaan mengenai perilaku terhadap hipertensi dan 16 pertanyaan tambahan mengenai aktivitas fisik. Pada artikel ini, kuesioner yang dibahas hanyalah kuesioner mengenai tingkat pengetahuan terhadap hipertensi.

\section{HASIL DAN PEMBAHASAN}

\section{Senam jantung sehat}

Sebanyak 30 peserta berpartisipasi dalam rangkaian kegiatan senam jantung sehat. Peserta terdiri dari ibu-ibu kader di Desa Cibeureum Wetan maupun warga masyarakat yang tergabung dalam Kelompok Tani Simpay Tampomas di Kecamatan Cimalaka, Kabupaten Sumedang. Sebelum dilakukan senam, para peserta terlebih dahulu diperiksa tekanan darah sistol maupun diastolnya oleh tim PPM.

Kegiatan senam dilakukan di halaman aula desa dengan bantuan sound system sederhana yang memutar lagu pendamping senam jantung sehat. Peragaan senam jantung sehat dilakukan oleh tim PPM, dan seluruh peserta dengan semangat mengikuti rangkaian pemanasan, gerakan inti senam, maupun pendinginan.

Setelah senam, dilakukan juga pemberian video senam dari tim PPM kepada perwakilan peserta. 
Diharapkan bahwa kelak ibu-ibu kader atau warga lainnya dapat berlatih senam ini secara mandiri untuk kemudian mengajak warga lain bersamasama melakukan senam jantung sehat secara rutin. Senam yang dilakukan secara rutin diharapkan dapat membantu warga untuk melakukan aktivitas fisik secara mudah dan menyenangkan, yang kemudian dapat membantu mengendalikan tekanan darah dan mencegah hipertensi.

\section{Kuesioner tingkat pengetahuan masyarakat terkait hipertensi}

Dari 30 warga yang hadir pada kegiatan senam jantung sehat, sebanyak 26 warga mengisi kuesioner dengan lengkap. Responden terdiri dari 22 orang wanita dan 4 orang laki-laki dengan rentang usia 23 hingga 65 tahun. Sebagian besar peserta bekerja sebagai ibu rumah tangga dan memiliki pendidikan terakhir sekolah dasar. Dari 11 pertanyaan mengenai pengertian, gejala dan tanda, faktor risiko, pengobatan, dan pencegahan hipertensi; rata-rata responden menjawab 7 pertanyaan dengan benar (nilai 63\% dari 100\%). Jumlah jawaban benar yang paling banyak dipilih oleh peserta (42\%) adalah 7 jawaban benar.

\section{SIMPULAN}

Pada kegiatan pengabdian pada masyarakat yang terintegrasi kuliah kerja nyata mahasiswa serta penelitian mengenai model mencit hipertensi ini, telah dilakukan pelatihan senam jantung sehat kepada warga di Desa Cibeureum Wetan, Kecamatan Cimalaka. Selain peragaan senam, diberikan juga video senam jantung sehat kepada perwakilan masyarakat. Pelatihan senam jantung sehat dari tim PPM ini diharapkan dapat menjadi awal untuk warga dapat melakukan senam rutin secara mandiri. Kegiatan aktivitas fisik rutin seperti senam diharapkan dapat membantu masyarakat dalam mencegah berkembangnya penyakit hipertensi.

Dari pengisian kuesioner mengenai tingkat pengetahuan hipertensi, didapati bahwa belum semua warga memiliki pengetahuan yang baik mengenai hipertensi. Edukasi mengenai hipertensi sebaiknya diberikan kepada masyarakat, misalnya melalui penyuluhan ataupun media poster. Untuk rangkaian kegiatan pengabdian kepada masyarakat selanjutnya, dapat diberikan penyuluhan dengan media interaktif seperti presentasi power point dengan bahasa yang mudah dimengerti oleh awam. Peningkatan pengetahuan mengenai hipertensi diharapkan dapat membantu masyarakat untuk bisa memodifikasi gaya hidupnya guna mencegah hipertensi.

\section{UCAPAN TERIMA KASIH}

Ucapan terima kasih Kami ucapkan kepada seluruh warga Desa Cibeureum Wetan, Kecamatan Cimalaka, Kabupaten Sumedang, khusunya kepada para warga desa yang tergabung dalam Kelompok Tani Simpay Tampomas. Kegiatan PPM yang terintegrasi kegiatan KKN mahasiswa ini didanai oleh hibah Riset Fundamental Universitas Padjadjaran (RFU) untuk penelitian mengenai model mencit hipertensi.

\section{DAFTAR PUSTAKA}

Fakhrudin, H., \& Nisa, K. (2013). Pengaruh senam jantung sehat terhadap kadar glukosa darah puasa pada lansia di Panti Sosial dan Lanjut Usia Tresna Werdha, Lampung Selatan. Medical Journal of Lampung University, 2(5), 76-84.

Kementerian-Kesehatan. (2019). Hipertensi penyakit paling banyak diidap masyarakat.

Murbawani, E. A., Ss, D., \& Subagyo, H. W. (2012). Perbedaan Profil Lipid Pada Peserta Senam Jantung Sehat. Jurnal Gizi Indonesia: The Indonesian Journal of Nutrition, 1(2), 26-33. https://doi.org/10.14710/jgi.1.2.

Setiawan, G. W., \& Wungouw, H. I. S. (2013). Pengaruh Senam Bugar Lanjut Usia terhadap Kualitas Hidup Penderita Hipertensi. E-Biomedik (EBM), 1(2), 760-764.

Sirait, M. P. R., Saraswati, L. D., \& Udiyono, A. (2018). Perbedaan Tekanan Darah Berdasarkan Keikutsertaan Senam Pada Lansia Di Instalasi Geriatri Rsup Dr . Kariadi Semarang Tahun 2017, 6(April), 29-33.

Totok, H., \& Fahrun, N. R. (2017). Pengaruh Senam Hipertensi Lansia Terhadap Penurunan Tekanan Darah Lansia Dengan Hipertensi Di Panti Werda Darma Bhakti Kelurahan Panjang Surakarta. Jurnal Kesehatan, 10(1), 26-31. https://doi.org/10.13040/ IJPSR.0975-8232.6(2).688-91

WHO Regional Office for South-East Asia. (2011). Hypertension fact sheet. Hypertension, 1-2.

World Health Organization. (2013). A global brief on Hypertension - World Health Day 2013. World Health Organization, 1-40. https://doi. org/10.1136/bmj.1.4815.882-a 